\title{
ANALISIS KESALAHAN MAHASISWA DALAM MEYELESAIKAN SOAL HIMPUNAN DI PROGRAM STUDI PENDIDIKAN MATEMATIKA UIN SUSKA RIAU
}

\author{
Lies Andriani \\ Pendidikan Matematika, Fakultas Tarbiyah UIN Sultan Syarif Kasim Riau, Jl. H.R Soebrantas, Pekanbaru \\ Lies.andriani@uin-suska.ac.id
}

\begin{abstract}
Abstrak
The objective of this research is to describe kinds of error and causes in completing mathematical set problems. In this research sampling technique was used to take sample is purposive sampling. This research can be categorized as descriptive research involving 31 college students of mathematics education program the first semester of the academic year 2019/2020 as research participant. Data collection is done through tests and interviews. The test was used in the form of a five-item description test. The students' errors were identified and categorized into 7 types of errors namely inappropriate data, inappropriate procedure, omitted data, omitted conclusion, response level conflict, indirect manipulation, skill hierarchy problem. In addition to the above seven categories errors that fall into this category include not responding. The result of this research showed that most of the students' errors was on omitted conclusion with the percentage of $29,03 \%$ and followed by omitted data with $20,97 \%$, and response level conflict was $17,74 \%$. The factors that influence students to make mistakes in solving set problems are students do not understand some number concepts, do not understand the set operations and symbols, and are not proficient in proving a statement. Also, the students being embarrassed to ask questions in class which they have actually learned so that it causes students to answer based on prior knowledge.
\end{abstract}

Keywords: analysis, student's errors, set

\begin{abstract}
Abstrak
Penelitian ini merupakan penelitan deskriptif kualitatif. Tujuan penelitian ini yaitu untuk mengetahui jenis-jenis kesalahan yang dilakukan mahasiswa Program Studi Pendidikan Matemaika dalam menyelesaikan soal-soal materi himpunan dan untuk mengetahui faktor apa saja yang menjadi penyebab mahasiswa Program Studi Pendidikan Matematika melakukan kesalahan dalam menyelesaikan soal-soal materi himpunan. Penentuan subjek menggunakan teknik purposive sampling. Subjek pada penelitian ini berjumlah tiga puluh satu orang yang diambil dari mahasiswa Program Studi Pendidikan Matematika Semester satu TA. 2018/2019. Teknik pengumpulan data dalam penelitian ini adalah tes dan wawancara. Tes yang digunakan berbentuk tes uraian sebanyak lima butir soal. Berdasarkan hasil penelitian jenis kesalahan yang dilakukan siswa dalam menyelesaikan soal pada materi himpunan adalah data tidak tepat, prosedur tidak tepat, data hilang, konflik level respon, manipulasi tidak langsung, masalah hirarki keterampilan, selain dari 7 kategori yaitu mahasiswa tidak menjawab soal. Dari hasil penelitian diperoleh bahwa kesalahan yang sering dilakukan mahasiswa adalah kesimpulan hilang sebesar 29,03\%, data hilang sebesar 20,97\% dan konflik level respon sebesar 17,74\%. Faktorfaktor yang mempengaruhi mahasiswa melakukan kesalahan dalam menyelesaikan soal materi himpunan adalah mahasiswa belum paham dengan beberapa konsep bilangan, belum memahami operasi himpunan beserta simbolnya, dan belum mahirnya dalam membuktikan suatu pernyataan. Hal ini juga disebabkan mahasiswa malu bertanya di dalam kelas mengenai materi yang sebenarnya mereka telah pelajari sehingga mengakibatkan mahasiswa menjawab berdasarkan pengetahuan yang telah dimiliki sebelumnya.
\end{abstract}

Kata Kunci : Analisis, Kesalahan mahasiswa, Himpunan

Matematika memainkan peranan yang sangat penting dalam kehidupan sehari-hari. Berbagai bentuk simbol, rumus, konsep, definisi, teorema dan dalil digunakan untuk membantu manusia dalam melakukan perhitungan, pengukuran, penilaian, peramalan dan sebagainya. Oleh karena itu, tidak heran jika peradaban manusia berubah dengan pesat karena ditunjang oleh partisipasi matematika yang selalu mengikuti perubahan dan perkembangan zaman (Masykur \& Fathoni, 2007:41). Karena pentingnya matematika untuk dipelajari, tidak heran di Indonesia mulai dari tingkat sekolah dasar sampai perguruan 
tinggi dan bahkan sekarang pada tingkat taman kanak-kanak diberikan pelajaran matematika untuk membekali peserta didik dengan kemampuan berpikir logis, analitis, sistematis, kritis, kreatif dan kemampuan bekerja sama.

Kemampuan yang dicapai dari pelajaran matematika tidak lepas dari ciri utama dari matematika tersebut yaitu adanya penalaran deduktif, yaitu kebenaran suatu konsep atau pernyataan merupakan akibat logis dari kebenaran sebelumnya sehingga kaitan antar konsep atau pernyataan dalam matematika bersifat konsisten. Mengingat ciri utama tersebut maka belajar matematika haruslah suatu proses yang berkesinambungan untuk memperoleh konsep, ide, dan pengetahuan baru yang berdasarkan pengalaman-pengalaman sebelumnya. Oleh karena itu, untuk setiap materi peserta didik diharapkan benar-benar menguasai konsep yang diberikan karena konsep tersebut akan digunakan untuk mempelajari materi berikutnya (Sunarsi, 2010).

Selain itu, pembelajaran matematika juga tidak akan terlepas dari karakterististik matematika yaitu memiliki objek kajian yang abstrak (Hariyani, 2014: 9). Karakterististik ini menuntut peserta didik, terutama mahasiswa pendidikan matematika sebagai calon guru yang telah memiliki tingkat berfikir lebih tinggi untuk dapat memahami makna dari objek abstrak dari matematika tersebut sehingga tidak terjadi kesalahan dalam penafsiran. Adanya karakteristik matematika ini juga menjadi salah satu penyebab mahasiswa mengalami kesulitan dalam memahami pembelajaran matematika.

Kesulitan tersebut dapat dilihat secara jelas dari ketidakmampuan mahasiswa dalam menyelesaikan soal yang diberikan oleh dosen. Mahasiswa mengalami kesulitan terlihat dari hasil pekerjaannya yang masih banyak terdapat kesalahan.

\section{Jenis Kesalahan dalam Mengerjakan Soal Matematika}

Kesalahan adalah kekeliruan, kekhilafan, sesuatu yang salah (Poerwadarminta, 2006: 855). Poerwadarminta (2006) juga menyatakan "Salah berarti tidak sebagaimana mestinya, tidak betul, tidak benar, keliru sedangkan kesalahan berarti kekeliruan, penyimpangan dari yang seharusnya, sesuatu yang salah, perbuatan salah". Ade Mirza (1998) mengatakan bahwa jawaban yang tidak sesuai dengan kriteria yang ditetapkan dinyatakan sebagai jawaban yang salah.

Ada bermacam-macam jenis kesalahan dalam belajar matematika di antaranya menurut Lerner dalam Mulyono (2003) kesalahan umum yang dilakukan oleh anak berkesulitan belajar matematika adalah kekurangan pemahaman tentang simbol, nilai tempat, perhitungan, penggunaan proses keliru, dan tulisan yang tidak terbaca. Sedangkan menurut Arti Sriati (1994: 4), kesalahan siswa dalam mengerjakan soal matematika adalah; (1) Kesalahan terjemahan yaitu: kesalahan mengubah informasi ke ungkapan matematika atau kesalahan dalam memberi makna suatu ungkapan matematika, (2) Kesalahan konsep yaitu kesalahan memahami gagasan abstrak, (3) Kesalahan strategi yaitu kesalahan yang terjadi jika siswa memilih jalan yang tidak tepat yang mengarah ke jalan buntu, (4) Kesalahan sistematik yaitu kesalahan yang berkenaan dengan pemilihan yang salah atas teknik ekstrapolasi, (5) Kesalahan tanda yaitu kesalahan dalam memberikan atau menulis tanda atau notasi matematika, (6) Kesalahan hitung yaitu kesalahan menghitung dalam operasi matematika. 
Menurut Watson (dalam Kristayulita \& Nurhardiani, 2011:34) terdapat delapan kategori kesalahan dalam mengerjakan soal matematika, yaitu sebagai berikut; (1) Data tidak tepat (inappropriate data/id). Dalam kasus ini siswa berusaha mengoperasikan pada level yang tepat pada suatu masalah, tetapi siswa memilih informasi atau data yang tidak tepat, (2) Prosedur tidak tepat (inappropriate procedure/ip). Pada kasus ini siswa berusaha mengoperasikan pada level yang tepat pada suatu masalah, tetapi dia menggunakan prosedur atau cara yang tidak tepat, misalnya menggunakan prinsip atau rumus dengan cara tidak tepat, (3) Data hilang (omitted data/od) Gejala data hilang yaitu kehilangan satu data atau lebih dari respon siswa. Dengan demikian penyelesaian menjadi tidak benar. Mungkin respon siswa tidak menemukan informasi yang tepat, namun siswa masih berusaha mengoperasikan pada level yang tepat. (4) Kesimpulan hilang (omitted conclusion/oc). Gejala kesimpulan hilang adalah siswa menunjukkan alasan pada level yang tepat kemudian gagal menyimpulkan, (5) Konflik level respon (response level conflict/rlc). Gejala yang terkait dengan respon kesimpulan hilang adalah konflik level respon. Pada situasi ini siswa menunjukkan suatu kompetisi operasi pada level tertentu dan kemudian menurunkan ke operasi yang lebih rendah untuk kesimpulan, (6) Manipulasi tidak langsung (undirected manipulation/um). Siswa mengakui perlu mengoperasikan pada level tertentu dan berusaha menggunakan semua data pada penyelesaian. Suatu jawaban benar diperoleh dengan menggunakan alasan yang sederhana dan penuangan tidak logis atau acak. Gejala ini diamati sebagai manipulasi tidak langsung, (7) Masalah hirarki keterampilan (skill hierarchy problem/shp). Banyak pertanyaan matematika memerlukan beberapa keterampilan untuk menyelesaikannya. Masalah hirarki keterampilan ditunjukkan antara lain siswa tidak dapat menyelesaikan permasalahan karena kurang atau tidak tampak keterampilannya, (8) Selain ketujuh kategori di atas (above other/ao). Kesalahan siswa yang tidak termasuk pada ketujuh kategori di atas dikelompokkan dalam kategori ini. Kesalahan selain ketujuh kategori di atas diantaranya pengopian data yang salah dan tidak merespon.

\section{Faktor-Faktor Kesalahan Mahasiswa dalam Belajar Matematika}

Dalam segi kesalahan mahasiswa, Menurut Ischak dan Warji (1987: 19) faktor-faktor yang dapat menimbulkan kesalahan mahasiswa dalam matematika, yaitu; (1) Faktor-faktor internal yaitu faktorfaktor yang berasal dari dalam diri siswa itu sendiri baik yang bersifat biologis maupun yang bersifat psikologis misalnya kecerdasan, kelemahan fisik, sikap dan kebiasaan yang salah dalam mempelajari bahan pelajaran tertentu, (2) Faktor-faktor eksternal yaitu faktor-faktor yang berasal dari luar diri siswa itu sendiri, berupa lingkungan, baik yang berupa lingkungan alam misalnya tempat belajar, suasana, cuaca, penerangan, dan sebagainya, maupun yang berupa lingkungan sosial yaitu yang berhubungan dengan pergaulan manusia. Dari kedua faktor tersebut telihat bahwa kesalahan itu terjadi diakibatkan salah satunya oleh faktor yang berasal dari mahasiswa itu sendiri, terutama dari sikap dan kebiasaan yang salah dalam mempelajari bahan pelajaran tertentu sehingga dalam menyelesaikan soal siswa dapat melakukan berbagai jenis kesalahan tertentu.

Fakta kesalahan yang dilakukan mahasiswa dalam menyelesaikan soal matematika terjadi pada mahasiswa program pendidikan matematika Fakultas Tarbiyah dan Keguruan UIN Suska Riau. Hal itu 
didasarkan pada hasil Ujian Tengah Semester mahasiswa pada mata kuliah Himpunan dan Logika. Salah satu materi matematika yang biasanya mahasiswa sering melakukan kesalahan dalam menggunakan konsep dasar di dalam menyelesaikan soal yaitu materi himpunan. Di dalam materi himpunan ini mahasiswa sebagai calon guru matematika diajarkan mengenai pengertian himpunan, cara penyajian himpunan, hubungan antar himpunan, operasi himpunan, diagram venn dan menyelesaikan masalah menggunakan konsep himpunan. Pada materi himpunan ini mahasiswa dituntut untuk benarbenar menguasai materi yang diberikan, karena materi himpunan ini merupakan materi yang penting dalam kehidupan dan nantinya materi tersebut akan mereka ajarkan ketika menjadi seorang guru. Dalam kenyataannya mahasiswa kurang mampu memahami dan menguasai materi himpunan, sehingga banyak mahasiswa yang melakukan kesalahan dalam menyelesaikan soal matematika yang berhubungan dengan konsep himpunan.

Kesalahan dalam menyelesaikan soal matematika materi himpunan diantaranya adalah mahasiswa masih salah dalam menyatakan himpunan dalam mendaftarkan anggota dan notasi pembentuk himpunan. Sehingga berdampak salah juga dalam menggambarkannya ke dalam diagram venn. Selain itu, mahasiswa juga salah menggunakan data dan prosedur yang tepat dalam menyelesaikan soal yang berhubungan dengan konsep himpunan. Selain itu juga, mahasiswa mengalami kesalahan dalam hal memahami soal cerita yang berkaitan dengan himpunan. Hal itu disebabkan karena dalam menyelesaikan soal-soal cerita banyak mahasiswa yang mengalami kesulitan dalam mengidentifikasi apa saja yang diketahui di dalam soal sehingga salah dalam menafsirkannya ke dalam simbol matematika. Berikut ini salah satu hasil pekerjaan mahasiswa yang mengalami kesalahan menyatakan himpunan dengan mendaftarkan anggota dan notasi pembentuk himpunan.

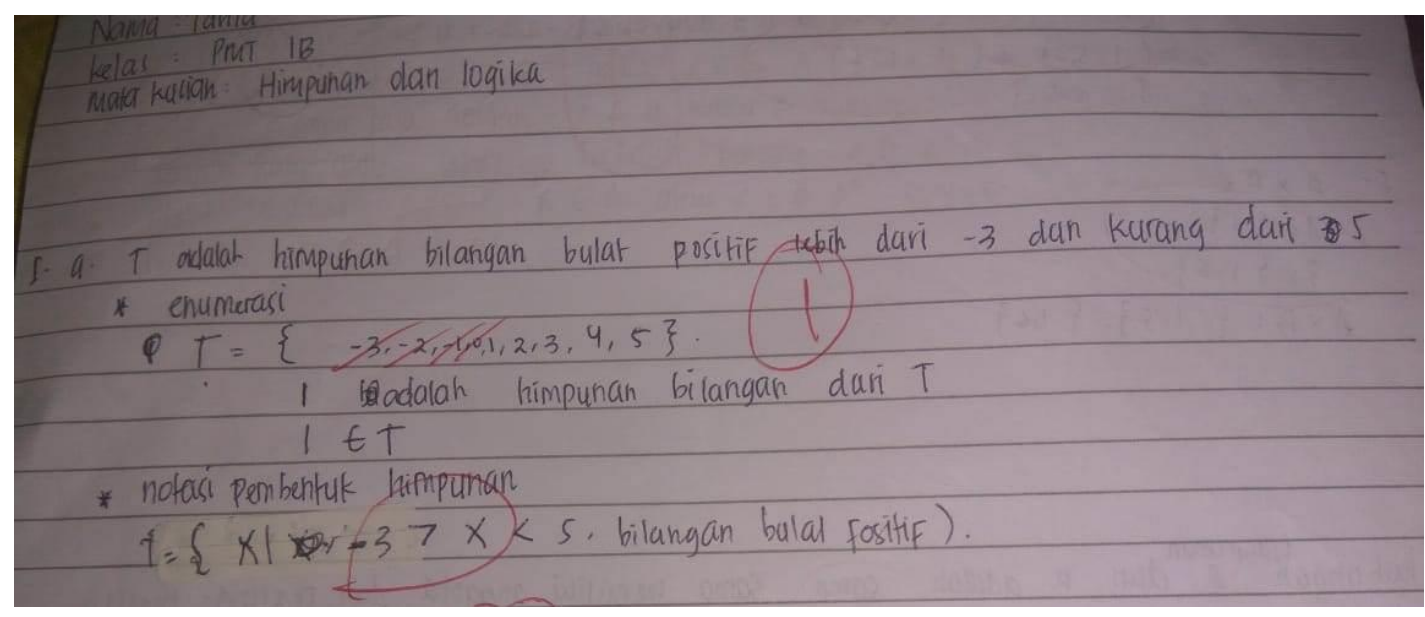

Gambar 1. Kesalahan Mahasiswa dalam Menyajikan Himpunan

Dari Gambar 1 terlihat bahwa mahasiswa mengalami kesalahan dalam menafsrikan konsep bilangan positif lebih dari -3 dan kurang dari 5 sehingga data yang digunakan menjadi tidak tepat mengakibatkan hasil yang diperoleh menjadi salah. Berdasarkan permasalahan adanya mahasiswa yang melakukan kesalahan di dalam menyelesaikan soal matematika materi himpunan dan ingin mengetahui penyebab kesalahan tersebut, maka peneliti merasa tertarik untuk melakukan penelitian yang berjudul "Analisis 
Kesalahan Mahasiswa dalam Menyelesaikan Soal Himpunan di Program Studi Pendidikan Matematika UIN Suska Riau". Adapun tujuan penelitian ini adalah sebagai berikut; (1) Untuk mengetahui jenisjenis kesalahan yang dilakukan mahasiswa Program Studi Pendidikan Matemaika dalam menyelesaikan soal-soal materi himpunan, (2) Untuk mengetahui faktor apa saja yang menjadi penyebab mahasiswa Program Studi Pendidikan Matematika melakukan kesalahan dalam menyelesaikan soal-soal materi himpunan.

\section{METODE}

Jenis penelitian yang digunakan adalah penelitian deskriptif kualitatif. Penelitian kualitatif adalah metode penelitian yang digunakan untuk meneliti pada kondisi objek yang alamiah, (sebagai lawannya adalah eksperimen) dimana peneliti adalah sebagai instrumen kunci, teknik pengumpulan data dilakukan secara trianggulasi (gabungan), analisis data bersifat induktif, dan hasil penelitian kualitatif lebih menekankan makna dari pada generalisasi (Sugiyono, 2009: 1). Metode kualitatif digunakan untuk mendapatkan data yang mendalam, suatu data yang mengandung makna. Makna adalah data yang sebenarnya, data yang pasti yang merupakan suatu nilai dibalik data yang tampak. Sementara penelitian diskriptif adalah penelitian yang berusaha mendiskripsikan suatu gejala atau peristiwa, kejadian yang terjadi pada saat sekarang. Dengan kata lain penelitian diskriptif mengambil masalah atau memusatkan perhatian kepada masalah-masalah aktual sebagaimana adanya pada saat penelitian dilaksanakan (Nana Sudjana, 2007: 64). Masalah yang dilihat dalam penelitian ini adalah kesalahan mahasiswa dalam menyelesaikan soal materi himpunan.

Penelitian dilaksanakan di Fakultas Tarbiyah dan Keguruan UIN Sultan Syarif Kasim Riau. Adapun yang menjadi subjek penelitian ini adalah mahasiswa Pendidikan Matematika Semester Satu TA. 2018/2019. Data yang diambil dalam penelitian adalah hasil ujian tengah semester mahasiswa pada materi himpunan dengan jumlah mahasiswa yang dijadikan subjek penelitian sebanyak 31 orang yang dipilih secara purposive sampling. Selain itu, data juga diambil dari hasil wawancara peneliti kepada 5 orang mahasiswa untuk melihat faktor penyebab mahasiswa melakukan kesalahan dalam menyelesaikan soal. Dari data tersebut, teknik pengumpulan data yang digunakan adalah tes dan wawancara. Jenis tes yang diberikan adalah essai sejumlah 5 soal yang berkaitan dengan penyelesaian soal matematika materi himpunan. Selanjutnya hasil pekerjaan siswa tersebut dikoreksi dan dianalisis guna untuk menentukan letak kesalahan siswa.

Penelitian ini menggunakan pendekatan kualitatif sehingga analisis datanya menggunakan analisis data kualitatif yang meliputi proses dan pemaknaan. Penelitian ini di dalamnya juga terdapat analisis deskriptif yang berfungsi untuk mendeskripsikan data penelitian. Analisis data disini dilakukan selama dan setelah pengumpulan data. Analisis ini digunakan untuk mengetahui kesalahan-kesalahan yang dilakukan siswa dalam menyelesaikan soal matematika materi himpunan dan faktor-faktor yang menyebabkan siswa melakukan kesalahan. Pada penelitian ini jenis kesalahan difokuskan pada jenis kesalahan berdasarkan kategori Watson. 
Rumus yang digunakan untuk menghitung persentase masing-masing jenis kesalahan berdasarkan kategori kesalahan yang dilakukan oleh mahasiswa adalah sebagai berikut (Paskalis, 2008: 21):

$$
P_{i}=\frac{n_{i}}{N} \times 100 \%
$$

Dimana:

$P_{i}=$ persentase masing-masing kategori kesalahan

$n_{i}=$ banyaknya kesalahan untuk masing-masing kategori kesalahan

$N$ = banyaknya kesalahan untuk seluruh kategori kesalahan

Untuk melihat klasifikasi persentase jenis kesalahan yang dilakukan mahasiswa, dapat dapat dilihat pada tabel berikut (Mujayanti, 2011: 31):

\section{Tabel 1}

Kriteria Persentase Kesalahan

\begin{tabular}{|c|c|}
\hline Persentase Kesalahan & Keterangan \\
\hline $\mathrm{P} \geq 55 \%$ & Sangat tinggi \\
\hline $40 \% \leq P<55 \%$ & Tinggi \\
\hline $25 \% \leq P<40 \%$ & Cukup tinggi \\
\hline $10 \% \leq P<25 \%$ & Kecil \\
\hline$P<10 \%$ & Sangat Kecil \\
\hline
\end{tabular}

\section{HASIL}

Data penelitian yang dikumpulkan adalah jenis kesalahan mahasiswa berdasarkan kategori Watson dalam menyelesaikan soal himpunan. Adapun kesalahan yang dilakukan oleh 31 mahasiswa dalam menjawab soal dapat dirincikan pada Tabel 2 berikut:

Tabel 2.

Kategori Kesalahan Mahasiswa dalam Menyelesaikan Soal Materi Himpunan

\begin{tabular}{|c|c|c|c|c|c|c|c|c|c|c|c|}
\hline \multirow{2}{*}{ Nama } & \multicolumn{10}{|c|}{ No Soal } \\
\cline { 2 - 13 } & $\mathbf{1 . a}$ & $\mathbf{1 . b}$ & $\mathbf{2 . a}$ & $\mathbf{2 . b}$ & $\mathbf{2 . c}$ & $\mathbf{2 . d}$ & $\mathbf{2 . e}$ & $\mathbf{2 . f}$ & $\mathbf{3}$ & $\mathbf{4}$ & $\mathbf{5}$ \\
\hline NL & 1 & 9 & 9 & 9 & 3 & 3 & 9 & 9 & 4 & 3 & 9 \\
\hline FJ & 1 & 9 & 9 & 9 & 3 & 3 & 2 & 9 & 5 & 3 & 9 \\
\hline INU & 1 & 9 & 3 & 1 & 1 & 1 & 1 & 3 & 4 & 3 & 9 \\
\hline LN & 1 & 9 & 9 & 9 & 3 & 3 & 9 & 9 & 4 & 9 & 9 \\
\hline MS & 1 & 3 & 1 & 3 & 3 & 3 & 3 & 3 & 5 & 3 & 7 \\
\hline WA & 9 & 9 & 9 & 9 & 3 & 3 & 9 & 9 & 5 & 3 & 9 \\
\hline TS & 9 & 9 & 9 & 9 & 6 & 9 & 6 & 6 & 4 & 3 & 9 \\
\hline DMS & 9 & 3 & 9 & 9 & 2 & 2 & 9 & 9 & 5 & 8 & 4 \\
\hline FH & 1 & 9 & 9 & 9 & 9 & 9 & 9 & 9 & 5 & 3 & 9 \\
\hline ADF & 9 & 9 & 9 & 9 & 2 & 5 & 3 & 9 & 4 & 5 & 3 \\
\hline N & 1 & 9 & 9 & 9 & 9 & 9 & 9 & 9 & 4 & 1 & 9 \\
\hline DA & 1 & 9 & 3 & 3 & 1 & 1 & 3 & 3 & 5 & 3 & 9 \\
\hline SAF & 9 & 9 & 9 & 9 & 3 & 3 & 9 & 9 & 4 & 9 & 9 \\
\hline MJ & 9 & 9 & 9 & 9 & 9 & 9 & 9 & 9 & 5 & 9 & 9 \\
\hline AA & 9 & 9 & 9 & 9 & 9 & 9 & 9 & 9 & 9 & 9 & 9 \\
\hline RW & 9 & 9 & 9 & 9 & 2 & 2 & 9 & 9 & 4 & 5 & 9 \\
\hline MF & 9 & 9 & 9 & 9 & 3 & 3 & 9 & 9 & 4 & 3 & 4 \\
\hline
\end{tabular}




\begin{tabular}{|c|c|c|c|c|c|c|c|c|c|c|c|}
\hline AF & 1 & 9 & 1 & 1 & 1 & 1 & 1 & 1 & 5 & 5 & 3 \\
\hline SA & 1 & 9 & 9 & 9 & 9 & 9 & 9 & 9 & 9 & 9 & 9 \\
\hline ME & 1 & 9 & 9 & 9 & 9 & 9 & 9 & 9 & 4 & 3 & 7 \\
\hline ISI & 9 & 9 & 9 & 9 & 9 & 9 & 9 & 3 & 5 & 3 & 6 \\
\hline RP & 1 & 9 & 9 & 9 & 9 & 9 & 9 & 9 & 5 & 5 & 9 \\
\hline WR & 1 & 9 & 9 & 9 & 2 & 2 & 9 & 5 & 4 & 5 & 9 \\
\hline ZM & 9 & 9 & 1 & 1 & 3 & 3 & 1 & 1 & 5 & 9 & 9 \\
\hline NIH & 1 & 9 & 9 & 9 & 2 & 2 & 3 & 9 & 4 & 5 & 4 \\
\hline NR & 9 & 9 & 3 & 3 & 1 & 3 & 3 & 3 & 5 & 9 & 9 \\
\hline WNZ & 8 & 8 & 9 & 9 & 6 & 9 & 6 & 5 & 4 & 3 & 7 \\
\hline ARH & 1 & 9 & 3 & 3 & 3 & 3 & 3 & 3 & 4 & 9 & 4 \\
\hline FNR & 9 & 9 & 9 & 9 & 9 & 9 & 9 & 9 & 9 & 1 & 9 \\
\hline AT & 1 & 3 & 9 & 9 & 2 & 2 & 2 & 9 & 8 & 3 & 6 \\
\hline T & 1 & 9 & 1 & 1 & 1 & 2 & 2 & 1 & 5 & 3 & 9 \\
\hline
\end{tabular}

Keterangan:

1 (data tidak tepat), 3 (prosedur tidak tepat), 4 (data hilang), 5 (konflik level respon), 6 (manipulasi tidak langsung), 7 (masalah hirarki keterampilan), 8 (selain dari 7 kategori/tidak menjawab), 9 (jawaban benar)

Secara rinci persentase kesalahan yang dilakukan mahasiswa dalam menjawab soal nomor 1.a dapat dilihat pada

Tabel 3.

Distribusi Frekuensi Kesalahan Siswa dan Persentase Kesalahan Siswa pada Soal Nomor 1.a

\begin{tabular}{|c|l|c|c|c|}
\hline No. & Kategori Kesalahan & Frekuensi & Persentase & Keterangan \\
\hline 1 & Data tidak tepat & 17 & $54,84 \%$ & Tinggi \\
\hline 2 & Selain ketujuh kategori & 1 & $3,22 \%$ & Sangat Kecil \\
\hline
\end{tabular}

Dari Tabel 3 terlihat bahwa dalam menjawab soal nomor 1.a mahasiswa tinggi melakukan kesalahan sebesar 54,84\% dalam menggunakan data tidak tepat sehingga memberikan jawaban yang salah. Pertanyaan dari nomor 1.a adalah sajikan himpunan T yaitu himpunan bilangan bulat positif tidak lebih dari -3 dan kurang dari 5 dengan cara enumerasi.

Selanjutnya, kategori kesalahan yang dilakukan mahasiswa dalam menjawab soal nomor 1.b adalah "data hilang" dan "kesalahan selain ketujuh kategori". Berikut distribusi frekuensi dan persentase masing-masing kategori kesalahan:

Tabel 4.

Distribusi Frekuensi Kesalahan Siswa dan Persentase Kesalahan Siswa pada Soal Nomor 1.b

\begin{tabular}{|c|l|c|c|c|}
\hline No. & Kategori Kesalahan & Frekuensi & Persentase & Keterangan \\
\hline 1 & Data hilang & 3 & $9,68 \%$ & Sangat Kecil \\
\hline 2 & Selain ketujuh kategori & 1 & $3,22 \%$ & Sangat Kecil \\
\hline
\end{tabular}

Dari Tabel 4 terlihat bahwa dalam menjawab soal nomor 1.b mahasiswa sangat kecil melakukan kesalahan yaitu data hilang dan selain ketujuh kategori. Pertanyaan dari nomor 1.b adalah sajikan himpunan L yaitu himpunan faktor dari 15 dengan cara enumerasi. 
Selanjutnya, kategori kesalahan yang dilakukan mahasiswa dalam menjawab soal nomor 2.a adalah "data tidak tepat" dan "data hilang". Berikut distribusi frekuensi dan persentase masing-masing kategori kesalahan:

\section{Tabel 5.}

Distribusi Frekuensi Kesalahan Siswa dan Persentase Kesalahan Siswa pada Soal Nomor 2.a

\begin{tabular}{|c|l|c|c|c|}
\hline No. & Kategori Kesalahan & Frekuensi & Persentase & Keterangan \\
\hline 1 & Data tidak tepat & 4 & $12,90 \%$ & Kecil \\
\hline 2 & Data hilang & 4 & $12,90 \%$ & Kecil \\
\hline
\end{tabular}

Dari Tabel 5 terlihat bahwa dalam menjawab soal nomor 2.a mahasiswa kecil melakukan kesalahan yaitu data tidak tepat dan data hilang. Pertanyaan dari nomor 2.a adalah diberikan himpunan-himpunan berikut: $\mathrm{U}$ adalah himpunan bilangan bulat nonnegatif kurang dari 9, A adalah bilangan asli kurang dari 4, B adalah himpunan bilangan asli tidak kurang dari 2 dan tidak lebih dari 6. Tentukan $A \cap B$.

Selanjutnya, kategori kesalahan yang dilakukan mahasiswa dalam menjawab soal nomor 2.b adalah "data tidak tepat" dan "data hilang". Berikut distribusi frekuensi dan persentase masing-masing kategori kesalahan:

\section{Tabel 6.}

Distribusi Frekuensi Kesalahan Siswa dan Persentase Kesalahan Siswa Pada Soal Nomor 2.b

\begin{tabular}{|c|l|c|c|c|}
\hline No. & Kategori Kesalahan & Frekuensi & Persentase & Keterangan \\
\hline 1 & Data tidak tepat & 4 & $12,90 \%$ & Kecil \\
\hline 2 & Data hilang & 4 & $12,90 \%$ & Kecil \\
\hline
\end{tabular}

Dari Tabel 6 terlihat bahwa dalam menjawab soal nomor 2.b mahasiswa kecil melakukan kesalahan yaitu data tidak tepat dan data hilang. Pertanyaan dari nomor 2.b adalah diberikan himpunan-himpunan berikut: $\mathrm{U}$ adalah himpunan bilangan bulat nonnegatif kurang dari 9, A adalah bilangan asli kurang dari 4, B adalah himpunan bilangan asli tidak kurang dari 2 dan tidak lebih dari 6. Tentukan $A \cup B$.

Kategori kesalahan yang dilakukan mahasiswa dalam menjawab soal nomor 2.c adalah "data tidak tepat", "prosedur tidak tepat", "data hilang", dan "manipulasi tidak langsung". Berikut distribusi frekuensi dan persentase masing-masing kategori kesalahan:

\section{Tabel 7.}

Distribusi Frekuensi Kesalahan Siswa dan Persentase Kesalahan Siswa pada Soal Nomor 2.c

\begin{tabular}{|c|l|c|c|c|}
\hline No. & \multicolumn{1}{|c|}{ Kategori Kesalahan } & Frekuensi & Persentase & Keterangan \\
\hline 1 & Data tidak tepat & 5 & $16,13 \%$ & Kecil \\
\hline 2 & Prosedur tidak tepat & 6 & $19,35 \%$ & Kecil \\
\hline 3 & Data hilang & 9 & $29,03 \% \%$ & Cukup Tinggi \\
\hline 4 & Manipulasi tidak langsung & 2 & $6,45 \%$ & Sangat Kecil \\
\hline
\end{tabular}

Dari Tabel 7 terlihat bahwa dalam menjawab soal nomor 2.c mahasiswa melakukan berbagai jenis kesalahan. Pertanyaan dari nomor 2.c adalah diberikan himpunan-himpunan berikut: U adalah 
himpunan bilangan bulat nonnegatif kurang dari 9, A adalah bilangan asli kurang dari 4, B adalah himpunan bilangan asli tidak kurang dari 2 dan tidak lebih dari 6. Tentukan $A^{c} \cup B^{c}$.

Kategori kesalahan yang dilakukan mahasiswa dalam menjawab soal nomor 2.d adalah "data tidak tepat", "prosedur tidak tepat", "data hilang", dan "konflik level respon”. Berikut distribusi frekuensi dan persentase masing-masing kategori kesalahan:

Tabel 8.

Distribusi Frekuensi Kesalahan Siswa dan Persentase Kesalahan Siswa pada Soal Nomor 2.d

\begin{tabular}{|c|l|c|c|c|}
\hline No. & Kategori Kesalahan & Frekuensi & Persentase & Keterangan \\
\hline 1 & Data tidak tepat & 3 & $9,68 \%$ & Kecil \\
\hline 2 & Prosedur tidak tepat & 6 & $19,35 \%$ & Kecil \\
\hline 3 & Data hilang & 10 & $32,26 \%$ & Cukup Tinggi \\
\hline 4 & Konflik Level respon & 1 & $3,22 \%$ & Sangat Kecil \\
\hline
\end{tabular}

Dari Tabel 8 terlihat bahwa dalam menjawab soal nomor 2.d mahasiswa melakukan berbagai jenis kesalahan. Pertanyaan dari nomor 2.d adalah diberikan himpunan-himpunan berikut: U adalah himpunan bilangan bulat nonnegatif kurang dari 9, A adalah bilangan asli kurang dari 4, B adalah himpunan bilangan asli tidak kurang dari 2 dan tidak lebih dari 6. Tentukan $A^{c}-B$.

Kategori kesalahan yang dilakukan mahasiswa dalam menjawab soal nomor 2.e adalah "data tidak tepat", "prosedur tidak tepat", "data hilang", dan "manipulasi tidak langsung". Berikut distribusi frekuensi dan persentase masing-masing kategori kesalahan:

Tabel 9.

Distribusi Frekuensi Kesalahan Siswa dan Persentase Kesalahan Siswa pada Soal Nomor 2.e

\begin{tabular}{|c|l|c|c|c|}
\hline No. & Kategori Kesalahan & Frekuensi & Persentase & Keterangan \\
\hline 1 & Data tidak tepat & 3 & $9,68 \%$ & Sangat Kecil \\
\hline 2 & Prosedur tidak tepat & 3 & $9,68 \%$ & Sangat Kecil \\
\hline 3 & Data hilang & 6 & $19,35 \%$ & Kecil \\
\hline 4 & Manipulasi tidak langsung & 2 & $6,45 \%$ & Sangat Kecil \\
\hline
\end{tabular}

Dari Tabel 9 terlihat bahwa dalam menjawab soal nomor 2.e mahasiswa melakukan berbagai jenis kesalahan. Pertanyaan dari nomor 2.e adalah diberikan himpunan-himpunan berikut: $U$ adalah himpunan bilangan bulat nonnegatif kurang dari 9, A adalah bilangan asli kurang dari 4, B adalah himpunan bilangan asli tidak kurang dari 2 dan tidak lebih dari 6. Tentukan $B \oplus A$.

Kategori kesalahan yang dilakukan mahasiswa dalam menjawab soal nomor 2.f adalah "data tidak tepat", "data hilang", "konflik level respon" dan "manipulasi tidak langsung". Berikut distribusi frekuensi dan persentase masing-masing kategori kesalahan:

Tabel 10.

Distribusi Frekuensi Kesalahan Siswa dan Persentase Kesalahan Siswa pada Soal Nomor 2.f

\begin{tabular}{|c|l|c|c|c|}
\hline No. & \multicolumn{1}{|c|}{ Kategori Kesalahan } & Frekuensi & Persentase & Keterangan \\
\hline 1 & Data tidak tepat & 3 & $9,68 \%$ & Sangat Kecil \\
\hline 2 & Data Hilang & 6 & $19,35 \%$ & Kecil \\
\hline
\end{tabular}




\begin{tabular}{|l|l|c|c|c|}
\hline 3 & Konflik level respon & 2 & $6,45 \%$ & Sangat Kecil \\
\hline 4 & Manipulasi tidak langsung & 1 & $3,22 \%$ & Sangat Kecil \\
\hline
\end{tabular}

Berdasarkan Tabel 10 terlihat bahwa dalam menjawab soal nomor 2.f mahasiswa melakukan berbagai jenis kesalahan. Pertanyaan dari nomor 2.f adalah diberikan himpunan-himpunan berikut: U adalah himpunan bilangan bulat nonnegatif kurang dari 9, A adalah bilangan asli kurang dari 4, B adalah himpunan bilangan asli tidak kurang dari 2 dan tidak lebih dari 6. Tentukan $A x B$.

Kategori kesalahan yang dilakukan mahasiswa dalam menjawab soal nomor 3 adalah "kesimpulan hilang", "konflik level respon" dan "selain ketujuh kategori". Berikut distribusi frekuensi dan persentase masing-masing kategori kesalahan:

Tabel 11.

Distribusi Frekuensi Kesalahan Siswa dan Persentase Kesalahan Siswa pada Soal Nomor 3

\begin{tabular}{|c|l|c|c|c|}
\hline No. & Kategori Kesalahan & Frekuensi & Persentase & Keterangan \\
\hline 1 & Kesimpulan hilang & 14 & $45,16 \%$ & Tinggi \\
\hline 2 & Konflik level respon & 13 & $41,93 \%$ & Tinggi \\
\hline 3 & Selain ketujuh kategori & 1 & $3,22 \%$ & Sangat Kecil \\
\hline
\end{tabular}

Dari Tabel 11 terlihat bahwa dalam menjawab soal nomor 3 mahasiswa paling tinggi melakukan kesalahan yaitu kesimpulan hilang. Pertanyaan dari nomor 3 adalah apa hubungan antara himpunan A dan B pada soal no 2? Jelaskan!

Kategori kesalahan yang dilakukan mahasiswa dalam menjawab soal nomor 4 adalah "data tidak tepat", "data hilang", "konflik level respon" dan "selain ketujuh kategori". Berikut distribusi frekuensi dan persentase masing-masing kategori kesalahan:

\section{Tabel 12}

Distribusi Frekuensi Kesalahan Siswa dan Persentase Kesalahan Siswa pada Soal Nomor 4

\begin{tabular}{|c|l|c|c|c|}
\hline No. & Kategori Kesalahan & Frekuensi & Persentase & Keterangan \\
\hline 1 & Data tidak tepat & 2 & $6,45 \%$ & Sangat Kecil \\
\hline 2 & Data hilang & 14 & $45,16 \%$ & Tinggi \\
\hline 3 & Konflik level respon & 6 & $19,35 \%$ & Kecil \\
\hline 4 & Selain ketujuh kategori & 1 & $3,22 \%$ & Sangat Kecil \\
\hline
\end{tabular}

Berdasarkan Tabel 12 terlihat bahwa dalam menjawab soal nomor 4 mahasiswa paling tinggi melakukan kesalahan yaitu data hilang. Pertanyaan dari nomor 4 adalah tentukan semua himpunan bagian dari himpunan $L$ pada soal no 1 !

Kategori kesalahan yang dilakukan mahasiswa dalam menjawab soal nomor 5 adalah "data hilang", "kesimpulan hilang" "manipulasi tidak langsung" dan "masalah hirarki keterampilan". Berikut distribusi frekuensi dan persentase masing-masing kategori kesalahan: 


\section{Tabel 13}

Distribusi Frekuensi Kesalahan Siswa Dan Persentase Kesalahan Siswa Pada Soal Nomor 5

\begin{tabular}{|c|l|c|c|c|}
\hline No. & \multicolumn{1}{|c|}{ Kategori Kesalahan } & Frekuensi & Persentase & Keterangan \\
\hline 1 & Data hilang & 2 & $6,45 \%$ & Sangat Kecil \\
\hline 2 & Kesimpulan hilang & 4 & $12,90 \%$ & Kecil \\
\hline 3 & Manipulasi tidak langsung & 2 & $6,45 \%$ & Sangat Kecil \\
\hline 4 & Masalah hirarki keterampilan & 3 & $9,68 \%$ & Kecil \\
\hline
\end{tabular}

Berdasarkan Tabel 13 terlihat bahwa dalam menjawab soal nomor 5 mahasiswa paling tinggi melakukan kesalahan yaitu data hilang. Pertanyaan dari nomor 5 adalah buktikan bahw $A \cap(B \cup C)=(A \cap B) \cup$ $(A \cap C) !$

Berdasarkan hasil wawancara yang peneliti lakukan dengan lima orang mahasiswa diperoleh faktorfaktor yang mempengaruhi mahasiswa melakukan kesalahan dalam menyelesaikan soal materi himpunan adalah mahasiswa belum paham dengan konsep bilangan, belum memahami operasi himpunan beserta simbolnya, dan belum mahirnya dalam membuktikan suatu pernyataan. Hal ini juga disebabkan mahasiswa malu bertanya di dalam kelas mengenai materi yang sebenarnya mereka telah pelajari sehingga mengakibatkan mahasiswa menjawab berdasarkan pengetahuan yang telah dimiliki sebelumnya.

\section{KESIMPULAN}

Temuan-temuan penelitian yang berkaitan dengan kesalahan siswa dalam menyelesaikan soal matematika materi himpunan diantaranya sebagai berikut:

1. Persentase rata-rata kesalahan data tidak tepat dalam menyelesaikan soal matematika materi himpunan sebesar 16,53\% yang mempunyai arti tingkat kesalahannya kecil.

2. Persentase rata-rata kesalahan prosedur tidak tepat dalam menyelesaikan soal matematika materi himpunan sebesar 16,93\% yang mempunyai arti tingkat kesalahannya kecil.

3. Persentase rata-rata kesalahan data hilang dalam menyelesaikan soal matematika materi himpunan sebesar 20,97\% yang mempunyai arti tingkat kesalahannya kecil.

4. Persentase rata-rata kesalahan kesimpulan hilang dalam menyelesaikan soal matematika materi himpunan sebesar 29,03\% yang mempunyai arti tingkat kesalahannya cukup tinggi.

5. Persentase rata-rata kesalahan konflik level respon dalam menyelesaikan soal matematika materi himpunan sebesar $17,74 \%$ yang mempunyai arti tingkat kesalahannya kecil.

6. Persentase rata-rata kesalahan manipulasi tidak langsung dalam menyelesaikan soal matematika materi himpunan sebesar 5,64\% yang mempunyai arti tingkat kesalahannya sangat kecil.

7. Persentase rata-rata kesalahan hirarki keterampilan dalam menyelesaikan soal matematika materi himpunan sebesar 9,68\% yang mempunyai arti tingkat kesalahannya sangat kecil.

8. Persentase rata-rata kesalahan selain ketujuh kategori dalam menyelesaikan soal matematika materi himpunan sebesar 3,22\% yang mempunyai arti tingkat kesalahannya sangat kecil. 
9. Kesalahan mahasiswa untuk kategori selain ketujuh kategori yang dilakukan adalah siswa tidak menjawab perrtanyaan soal hanya mengulang apa yang diketahui dalam soal.

10. Berdasarkan hasil wawancara yang peneliti lakukan dengan beberapa mahasiswa diperoleh faktorfaktor yang mempengaruhi mahasiswa melakukan kesalahan dalam menyelesaikan soal materi himpunan adalah mahasiswa belum paham dengan konsep bilangan, belum memahami operasi himpunan beserta simbolnya, dan belum mahirnya dalam membuktikan suatu pernyataan. Hal ini juga disebabkan mahasiswa malu bertanya di dalam kelas mengenai materi yang sebenarnya mereka telah pelajari sehingga mengakibatkan mahasiswa menjawab berdasarkan pengetahuan yang telah dimiliki sebelumnya.

Berdasarkan kesimpulan di atas maka ada beberapa saran yang diajukan peneliti untuk mengatasi kesalahan-kesalahn siswa yang dilakukan mahasiswa dalam menyelesaikan soal matematika materi himpunan yaitu untuk tenaga pengajar sebaiknya sebelum mengajar materi himpunan terlebih dahulu mengecek kembali pengetahuan materi prasyarat yang dimiliki mahasiswa sebelum mempelajari materi himpunan sehingga materi prasyarat tersebut bisa langsung dikaitkan dengan materi himpunan, contohnya konsep bilangan.

Selain itu, untuk meningkatkan kemampuan mahasiswa dalam membuktikan pernyataan tentang himpunan perlu dilakukan latihan berulang sehingga mahasiswa terbiasa dan tahu strategi yang dilakukan dalam membuktikan suatu pernyataan. Hal ini juga bisa dibarengi dengan memberikan beberapa cara/metode pembuktian sehingga mahasiswa bisa memilih metode mana yang mudah unttuk dipahami.

\section{DAFTAR PUSTAKA}

Hariyani, M. (2014). Konsep Dasar Matematika. Pekanbaru: Benteng Media.

Ischak dan Warji. (1987). Program Remedial dalam Proses Belajar Mengajar. Yogyakarta: Liberty.

Kristayulita \& Nurhardiani. (2011). Analisis Kesalahan dalam Menyelesaikan Persamaan Diferensial Orde-1 pada Mata Kuliah Persamaan Diferensial dengan Panduan Kriteria Watson. Jurnal Tadris Matematika (Beta). 4 (1), 30-52. Nusa Tenggara Timur, UIN Mataram.

Masykur, M \& Fathoni, A.H. (2007) Mathematical Intelegence. Jogyakarta: Ar-Ruzz Media. Mirza, A. (1998). Analisis Kesalahan Belajar Matematika. Pontianak: FKIP UNTAN.

Mujayanti, N. (2011). Analisis Kesalahan Siswa Berdasarkan Kategori Kesalahan Menurut Watson dalam Menyelesaikan Permasalahan Statistika Siswa Kelas XI IPA SMA Negeri 2 Genteng. Published Skripsi. Jember: Universitas Jember.

Mulyono, A. (2003). Pendidikan Bagi Anak Berkesulitan Belajar. Jakarta: PT Rineka Cipta.

Paskalis, Y. W. (2008). Analisis Kesalahan Siswa Kelas VII D dan VII E SMPK Maria Fatima Jember dalam Menyelesaikan Soal Cerita pada Pokok Bahasan Aritmetika Sosial Semester Ganjil Tahun Ajaran 2007/2008. Jember: Universitas Jember.

Poerwadarminta, W. J. S. (1984). Kamus Umum Bahasa Indonesia. Jakarta: Balai Pustaka. 
Poerwadarminta, W. J. S. (2006). Kamus Umum Bahasa Indonesia. Jakarta: Balai Pustaka

Sriati, A. (1994). Kesulitan Belajar Matematika pada Siswa SMA (Pengkajian Diagnosa). Jurnal Kependidikan. Jogjakarta

Sudjana, N. (2007). Penelitian dan Penilaian Pendidikan. Bandung: Sinar Baru Algensindo.

Sugiyono. (2009) Memahami Penelitian Kualitatif. Bandung: Alfabeta.

Sunarsi, A. Analisis Kesalahan dalam Menyelesaikan Soal pada Materi Luas Permukaan serta Volume Prisma dan Limas pada Siswa Kelas VIII Semester Genap SMP Negeri 2 Karanganyar. Published Thesis. Surakarta. Universitas Sebelas Maret. 